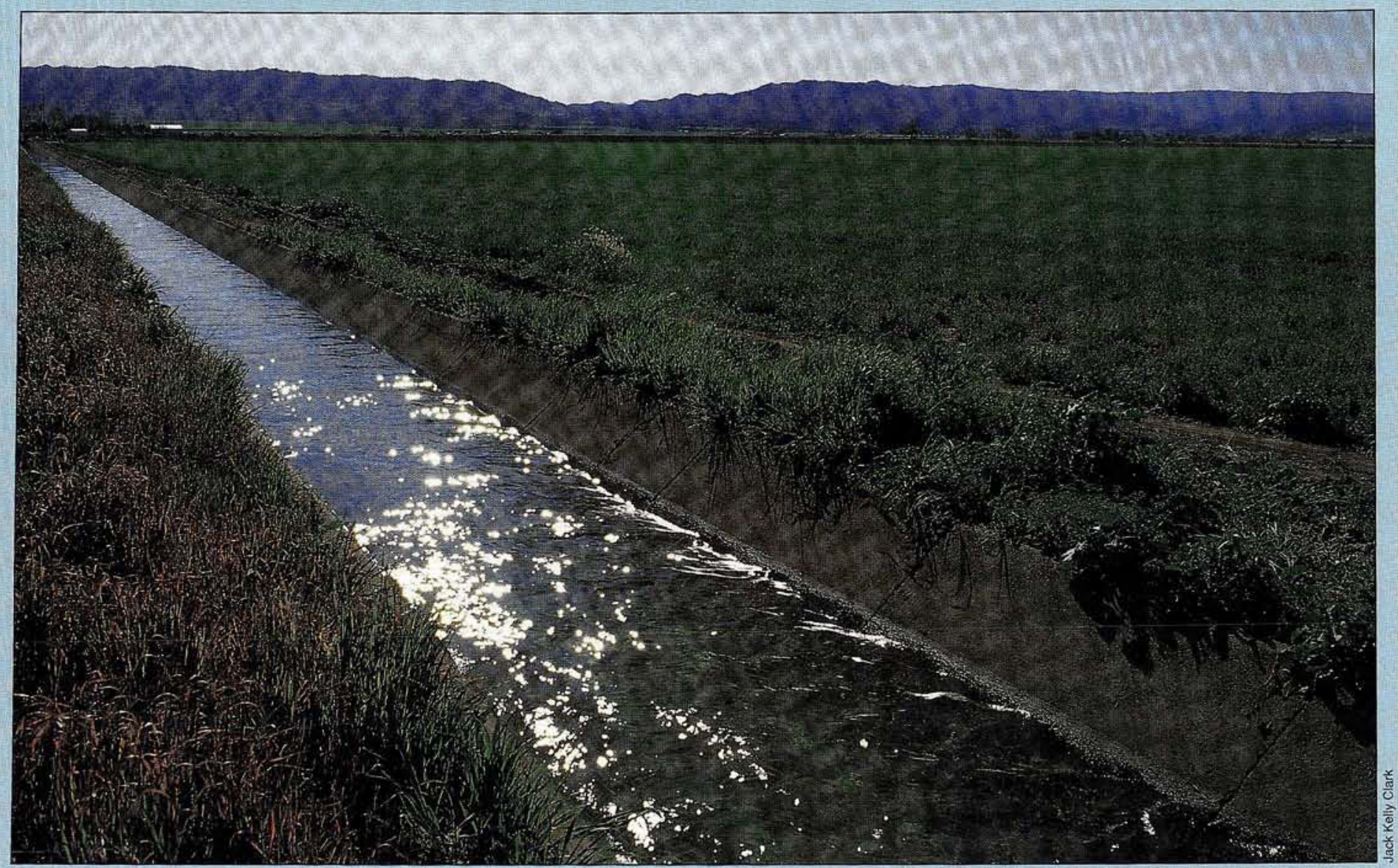

Concrete irrigation ditch near Winters in Yolo County.

\title{
'Well set aside' proposal: a scenario for ground water banking
}

\author{
Richard E. Howitt $\square$ Marangu M'Marete
}

\section{Experience with the last major drought in 1976-1977 shows that increased ground water pumping was the critical factor in avoiding economic hardship to farmers and consumers. However, the increase in pumping came with an equally large increase in ground water overdrafts. Such flexibility in water use in the future can only be main- tained if ground water is recharged in normal years.}

Water districts proposing to recharge depleted ground water basins often request additional surface water for this purpose. While some local water agencies, principally in the South San Joaquin Valley, have initiated successful recharge programs in this manner, there is also a need for incentives to modify the pattern of ground water use by private individuals. Changes in the structure of power rates for ground water pumping could help tilt the pattern of use to more closely fit California's fluctuating surface water supplies.

Currently, utility pricing methods inhibit change in the pattern of ground water use. The most efficient rate structure for power generation discourages flexible annual pumping by ground water users. A ground water banking proposal, based partly on restructured power rates, could provide incentives that would encourage pumping more in dry years, and less in normal years, preserving the current ability to respond to droughts.

\section{Current policy and practice}

California's ground water is critical to successful drought management, however, the undefined and unregulated nature of California's ground water rights prevents any centrally administered scheme. Because strong opposition to ground water regulation can be expected to persist for the foreseeable future, a method for maintaining drought flexibility will have to be based on incentives to individual pumpers.

The cost of ground water to the individual is composed of the fixed costs of well establishment, and the operating costs which are dominated by demand and energy payments to the power utility. Utilities have to provide the generating capacity for potential connected loads. Since generating capacity costs have a high fixed cost component, the power charges to agricultural users reflect this in the demand charge, currently in the range of $\$ 2.20$ / horsepower/month. A connected well owner pays the demand, metering and connection charge for all wells connected to power. In addition, if the well is activated at any time in a year the full 12 

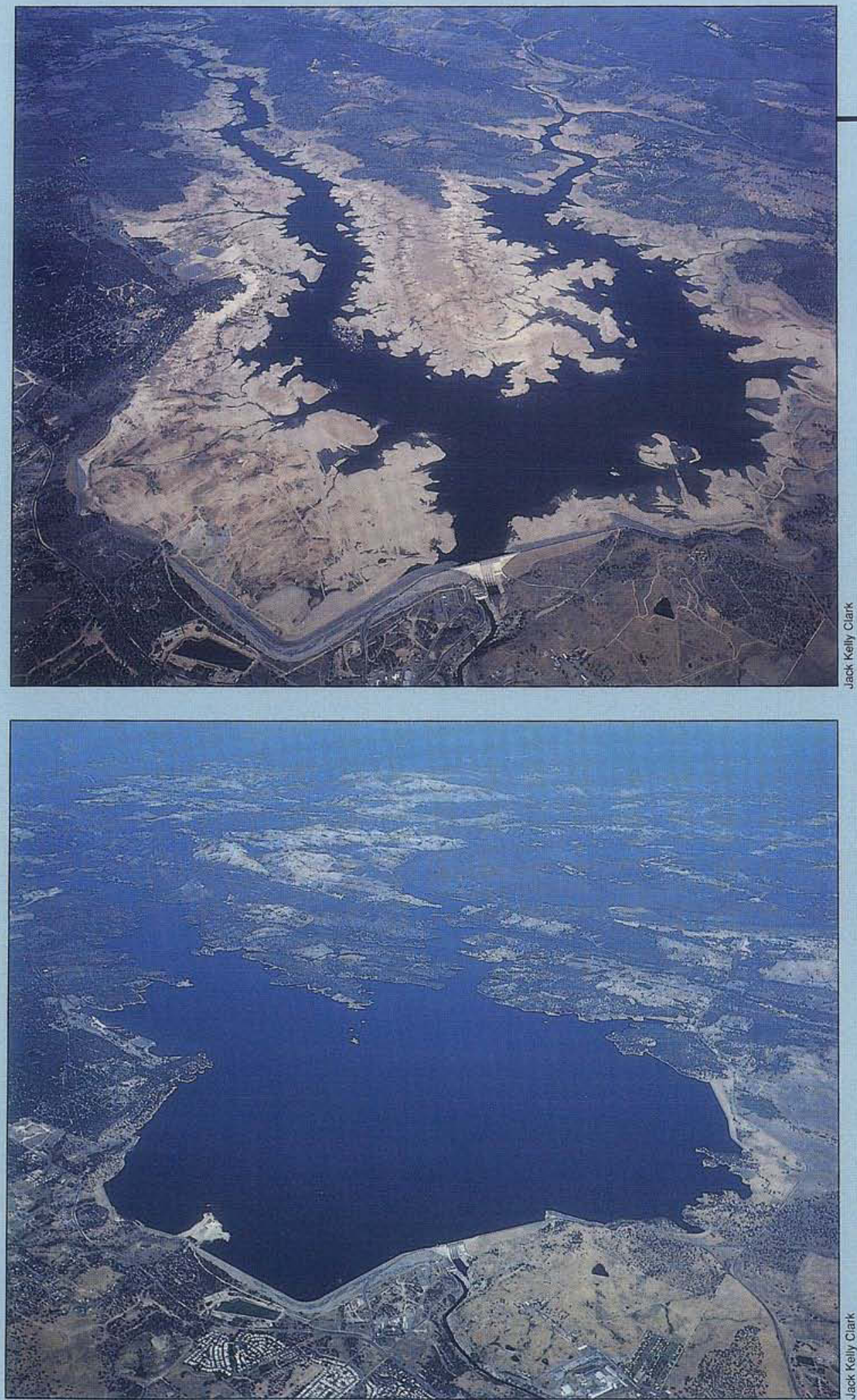

Contrasting photographs of Folsom Dam near Sacramento show water levels at the height of the 1976-1977 drought (above), and after the 1978 rains (below). Photographs were taken in September 1977 and June 1978. months of demand and connection charges are assessed.

These utility pricing methods reflect power costs and are designed to minimize the cost of providing power by encouraging a steady demand. The problem is that the economically efficient way to use power does not provide incentives for the most flexible and economic use of ground water.

New well users have a strong incentive to pump steadily regardless of wet or dry years. In most cases, a new connection contracts to pay the full demand and connection charges for three years, even if the well is not used. The ideal incentive structure for a flexible ground water response would encourage well installation, but no use until a dry year.

\section{The ground water bank}

Drought response would be enhanced by a ground water banking or 'well set aside' program that lowered the cost of pumping ground water in critical and drought years to well users who opted not to pump in normal and wet years. A program would require a reduced or zero demand charge for those in the set aside program. Utilities would have to be compensated for the underutilized generating capacity. In addition, new wells put in the set aside program would be exempt from the three-year demand charge contract.

The recent response to the drought water bank was in some cases provided by growers who sold their surface water rights, and utilized their ground water rights at an average level for the region. If those growers who had put wells in the ground water bank in the past, and so had built up some ground water "credits," were given the first option to sell water in dry years, this could be an added and valuable incentive for private ground water banking. A more extreme position would be to restrict sales of surface water, where ground water was substituted, to those who had participated in the well set aside program.

Funds to cover this program could be generated by raising the demand charges or power charges to ground water pumpers not in the program. While operating through the utilities' billing system, the costs and operation of the set aside program should be borne by a state water agency, since the program's aim is ground water conservation. Critical and dry years could be determined using the "four river index" which helps govern dam releases 
in California's Central Valley. (Surface water flows in any given year are measured by an index of the flow in four key rivers: the American, Sacramento, Feather and Yuba Rivers.) If there are no retroactive fixed demand charges, a determination in February or March each year would enable growers to respond with normal or dry year pumping strategies.

Two problems arise from the outline of this ground water banking scheme. First: What if pumpers don't react to the demand cost reductions?' The answer would be to also tilt the power rates in the direction of the set aside program. Domestic energy users have responded to time of use and efficiency incentives offered by utilities. Agricultural well pumpers are now faced with a range of rate schedules. Their response to these rate changes would enable a program to be developed.

A second problem that does not have an easy answer is: 'What stops a pumper from putting one well in the set aside program and pumping additional water in normal years from an adjoining well?' The answer is that nothing can be done about this problem under existing ground water rights. The degree of slippage in the program due to this switching needs to be estimated.

\section{Summary}

Normal years are not normal in California's variable water supply. The most common occurrence is a wet or a dry year. Droughts are the dominant consideration in planning surface water systems. The ability to respond under drought conditions is a very valuable aspect of California's ground water resources. However, given the persistent overdrafts of ground water in normal years, the ground water stocks and extraction capacity may be lacking in future droughts.

As California's water supplies get increasingly costly and scarce, ground water use must respond to the natural variability. Ground water pumpers have shown that they can respond, but the incentives to maintain this ability to respond to drought are currently absent in California's pumping rate structure. A self financing ground water banking program could provide an alternative incentive structure that would maintain a flexible response.

R.E. Howitt is Professor, Department of Agricultural Economics, UC Davis, and $M$. M'Marete is Operations Research Specialist at the California Department of Water Resources.
First assumption: Surface water supplies to agriculture would be cut by an average of $80 \%$. (This reflects announcements made before the recent March storms of $100 \%$ cuts by the State Water Project, $75 \%$ cuts by Federal Central Valley Project and similar cuts by other water supply agencies.)

Second assumption: Ground water pumping would increase up to $70 \%$, a figure based on past experience and current well capacity. As a result, net water use would drop somewhat, but far less than the reduction in the surface supply. The assumed net regional reductions in irrigation water use were:

- Sacramento region (Tehama, Glenn, Butte, Colusa, Yuba, Sutter, Yolo, Sacramento, Solano Counties): $12 \%$.

- North San Joaquin Valley (SJV) region (San Joaquin, Stanislaus, Merced Counties): $17 \%$.

- Central SJV region (Madera, Fresno, Tulare, Kings Counties): $20 \%$.

- South SJV region (Kern County): $30 \%$.

- Bay Area and Northern Coastal region: $10 \%$.

- Central and South Coast region: $35 \%$.

- Imperial and Coachella Valley region: No reduction.

For the entire Central Valley, the average 1991 reduction in water use was assumed to be just under $18 \%$. (This is a weighted average, taking into account regional water use in a normal year.)

Third assumption: Average water costs to farmers would double. This figure used by the CAR model is, obviously, an estimate. It is based on the following reasoning: Farmers would have to pay some fixed charges for surface water even if they did not receive it. Furthermore, ground water pumping costs would be higher than normal because of higher power rates, deeper depths and use of some less efficient pumps. Part of the available surface water would come from transfers costing $\$ 130$ or more per acre foot even before conveyance. Overall, doubling of water costs is an ad hoc assumption, but probably not far off.

Fourth assumption: Perennial crops, with most capital cost and crop income at risk, would bid most for the scarce supply; as a result, sufficient water would move within regions so that $95 \%$ of tree and vine crops would produce normal yields. Thus, perennial crop producers would find it worthwhile to buy water from the Water Bank for $\$ 140$ plus conveyance costs. It was also assumed that annual crops would not be planted unless the grower had a reasonable expectation of enough water to bring the crop to maturity. Therefore, per-acre yields of the annual crop acreage that is planted would be close to normal.

\section{Impacts on acreage}

Using these assumptions, the CAR model projected statewide crop acreage changes during the 1991 drought-impacted growing season. Estimated changes for those crops most affected are shown in table 1.

Differences among the various crops in the table are largely due to the fact that greater decreases in acreage can be expected for (1) higher water-use crops and (2) lower per-acre value crops. Irrigated pasture, for example, fits both of those categories; and irrigated pasture is projected

\begin{tabular}{|lcc|}
\hline \multicolumn{1}{|c|}{ TABLE 1. Projected acreage changes given the 1991 drought assumptions } \\
\hline \hline & Acres removed & $\begin{array}{c}\text { Percentage reduction } \\
\text { below } 1987 \text { - a normal year }\end{array}$ \\
\hline & $\times 1000$ & $\%$ \\
Total & $1,252.0$ & 14 \\
Crops with major & & \\
changes & & \\
Alfalfa hay & & \\
Cotton & 293.0 & 28.7 \\
Silage & 280.5 & 23.0 \\
Melons & 17.5 & 11.0 \\
Rice & 19.4 & 15.7 \\
Sugar beet & 33.9 & 8.7 \\
Irrigated wheat & 40.1 & 17.6 \\
Irrigated barley & 52.6 & 10.7 \\
Grain sorghum & 45.3 & 27.7 \\
Pasture & 5.8 & 32.2 \\
\hline
\end{tabular}

